\title{
Physical and Mechanical Properties of Custard Apple Fruit (Annona squamosa L.)
}

\author{
Sonali C. Khanbarad ${ }^{1 *}$ and P. H. Bakane ${ }^{2}$ \\ Department of Agricultural Process Engineering, Dr PDKV, Akola, India \\ *Corresponding author
}

\section{A B S T R A C T}

\section{Keywords \\ Custard apple, Peel, seeds, Seeded pulp, \\ Physical and \\ Mechanical \\ properties \\ Article Info \\ Accepted: \\ 17 August 2020 \\ Available Online: \\ 10 September 2020}

\begin{abstract}
Custard apple is one of the delicious fruits with pleasant flavour, mild aroma and sweet taste used for table purposes in India. Now a day, despite being an underutilized fruit with poor shelf life, many growers attempting to cultivate custard apple fruit for its nutritional and therapeutic use. Demand for custard apple fruit processing is also increasing for which development of processing technology or equipment is very necessary. Physical and mechanical properties differed according to the variety and size of custard apple fruits. Therefore, Knowledge of physical and mechanical property of custard apple fruit and seeds of large, medium and small size was important in order to provide useful data for the design of handling, storing and processing equipment. The mean length, width, thickness, size, arithmetic mean diameter, sphericity, surface area and volume custard apple fruit were $72.95,64.28,69.83,68.87,69.03,0.95,149.81$ and 174.05 respectively. The mean length, width, thickness, size, arithmetic mean diameter, sphericity, surface area and volume of custard apple seeds were $13.17 \mathrm{~mm}, 6.97 \mathrm{~mm}, 5.12 \mathrm{~mm}, 7.76 \mathrm{~mm}, 8.42 \mathrm{~mm}$, $0.59,1.89 \mathrm{~cm}^{2}$ and $0.25 \mathrm{~cm}^{3}$ respectively.
\end{abstract}

\section{Introduction}

Custard apple (Annona squamosa L.) is a very delicious and delicate fruit known as sharifa, sitaphal, sweet sop and sugar apple. Custard apple is widely grown fruit crop in Andhra Pradesh, Rajasthan, Karnataka and Maharashtra states and has good potential for value addition for socio-economic upliftment of farmers. It can be considered to be promising for the international market due to its excellent nutritional and organoleptic characteristics. However, because of its structure, it can easily get damaged, inducing changes in texture and physicochemical conditions that, in turn, limit its shelf life and reduce its quality when stored inappropriately (Telis-Romero et al., 2007). The textural and rheological properties of fruits are important attributes that influence their overall quality, storage and processing conditions, acceptability on the part of consumers, transportation, design, optimization, and selection of equipment (Jha et al., 2010, and Singh and Sreenivasula, 2006). One of the major characteristics that define the internal and external quality of a fruit is firmness. The edible portion of the fruit varies from 28 to 55 
per cent. The $100 \mathrm{~g}$ pulp contains $70.5 \mathrm{~g}$ moisture, $23.5 \mathrm{~g}$ carbohydrate, $1.6 \mathrm{~g}$ protein, $0.9 \mathrm{~g}$ minerals, $1.5 \mathrm{mg}$ iron, $17 \mathrm{mg}$ calcium, $47 \mathrm{mg}$ phosphorus and $37 \mathrm{mg}$ vitamin C (Dashora et al., 2004). It has a lot of medical benefits. The fruit, seeds and leaves have used traditionally in the management of stomach complaints, diarrheal, diabetes related diseases, cancer, fever and as well as sedatives in some parts of South and North America. It is one of the exotic fruits prized for its very pleasant, aromatic and juicy flesh in India. It is a highly perishable fruit with short shelf life but rich in vitamins $B_{1}, B_{2}$, and C. The optimum time taken for the unripe mature custard apple to ripe takes 5-6 days after harvest (Okoro and Osunde, 2013).

In climacteric fruits such as soursop, ripening is a complex, genetically controlled process marked by the synthesis and degradation of new compounds (Salisbury and Ross, 1994; Taiz and Zeiger, 2010). Some of the changes that occur during ripening and postharvest directly affect the shelf life and sensorial and nutritional quality of fruits (Hosakote et al., 2005; Wu et al., 2005).

In this context, the purpose of the present study was the assessment of the physical and mechanical features that express the most significant changes taking place in the different size of custard apple fruit.

\section{Materials and Methods}

The present research was carried out on custard apple fruits (Balalnagar variety). Uniform size and healthy fruits of custard apple were procured from local market, Akola for the experiments. To carry the studies on physical and mechanical parameters, three different well defined physical size (fruit diameter) grades viz., large (L- size range), medium (M- size range) and small(S- size range) were selected.

\section{Physical properties of custard apple fruit}

A digital balance with measurement precision of $\pm 0.1 \mathrm{~g}$ was used for weighing fruits, seeded pulp and peel. Three principal axes of custard apple fruit such as length (along major axis), width (along intermediate axis), thickness (along minor axis) and thickness of peel were measured using digital Vernier Calliper (Mitutoya, Japan Make) having a least count of $0.01 \mathrm{~mm}$. Fifty fruits were randomly selected and values for each parameter were recorded. Fruit size, arithmetic mean diameter, sphericity, surface area and volume were calculated.

\section{Physical properties of custard apple seeded pulp and seed}

Custard apple seeded pulp after separations from peel were evaluated for seeded pulp size, arithmetic mean diameter, sphericity and surface area. Spatial dimensions of seeds after separation from pulp were measured using digital Vernier Calliper (Mitutoya, Japan Make) having a least count of $0.01 \mathrm{~mm}$. Seed size, arithmetic mean diameter, sphericity and surface area and volume were calculated. Basic statistic of physical properties of custard apple fruit were carried out using software on MS-Excel.

\section{Geometric mean diameter (Dg)}

The size of fruit and seed was calculated by using following equation (Sreenarayanan et al., 1985 and Sharma et al., 1982).

$\mathrm{Dg}=(\mathrm{abc})^{1 / 3}$

Where

$\mathrm{L}=$ length (major axis), $\mathrm{mm}$

$\mathrm{W}=$ width (intermediate axis), $\mathrm{mm}$

$\mathrm{T}=$ thickness (minor axis), $\mathrm{mm}$ 


\section{Arithmetic mean diameter (Da)}

Arithmetic mean diameter (Da) for each custard apple fruit and seed was calculated by using following equation (Mohsenin, 1986).

$$
\mathrm{Da}=\frac{a+b+c}{3}
$$

Where, $\mathrm{Da}=$ Arithmetic mean diameter $(\mathrm{mm})$

$\mathrm{L}=$ length of fruit $(\mathrm{mm})$

$\mathrm{W}=$ width of fruit $(\mathrm{mm})$

$\mathrm{T}=$ thickness of fruit $(\mathrm{cm})$

\section{Sphericity $(\phi)$}

Sphericity of custard apple fruit and seed was determined by using following equation (Mohsenin, 1986).

$\phi=\frac{a x b x c^{1 / 3}}{a}$

Where, $\mathrm{L}=$ length (major axis), $\mathrm{mm}$

$\mathrm{W}=$ width (intermediate axis), $\mathrm{mm}$

$\mathrm{T}=$ breadth (minor axis), $\mathrm{mm}$

\section{Surface area (S)}

The surface area of custard apple fruit and seed was calculated by using below given formula (McCabe et al., 1986).

$\mathrm{S}=\pi \times \mathrm{Dg}$

Where, $\mathrm{S}=$ Surface area, $\left(\mathrm{cm}^{2}\right)$ $\mathrm{Dg}=$ Geometric mean diameter $(\mathrm{cm})$

\section{Volume of fruit (V)}

The volume of fruit and seed was calculated by considering the geometry of the object similar to the oblate spheroid shape. The volume was calculated by using following formulas (Mohsenin, 1986).

$$
\mathrm{V}=\frac{4}{3} \pi \frac{\mathrm{a}}{2} \frac{\mathrm{b}}{2} \frac{\mathrm{c}}{2}
$$

Where, $\mathrm{V}=$ volume of fruit $\left(\mathrm{cm}^{3}\right)$

$\mathrm{L}=$ length of fruit $(\mathrm{cm})$

$\mathrm{W}=$ width of fruit $(\mathrm{cm})$

$\mathrm{T}=$ thickness of fruit $(\mathrm{cm})$

\section{Seeded pulp content of fruit}

Seeded pulp content of fruit was calculated by using following formula (Kachhadiya and Jethva, 2017).

Seeded pulp content, $\%=\frac{\mathrm{A}}{\mathrm{W}} \times 100$

Where, $\quad A=$ Seeded pulp weight $(\mathrm{g})$

$\mathrm{W}=$ Weight of fruit $(\mathrm{g})$

\section{Peel content of fruit}

Peel content of fruit was calculated by using following formula (Kachhadiya and Jethva, 2017).

Peel content, $\%=\frac{\mathrm{B}}{\mathrm{W}} \times 100$

Where, $\mathrm{B}=$ Peel weight, $(\mathrm{g})$

$\mathrm{W}=$ Weight of fruit, $(\mathrm{g})$

\section{Mechanical properties}

Hardness is the force required to compress a substance between the molars, bite through with incisors, compress between tongue and palate to a given deformation or penetration and designated as soft, firm or hard or it is the highest value of force required to compress the sample during the first compression cycle (Peleg, 1996). Fracturability is the force value at the first peak of the first compression cycle with which the sample breaks. Fruit hardness was measured using a texture profile analyzer TA.HD Plus (Stable Micro System Ltd., UK) 
with $\mathrm{P} / 75,75 \mathrm{~mm}$ compression platen probe. The texture profile analyzer was calibrated with a $50 \mathrm{~kg}$ load cell. The operating conditions for the profile analyzer were as follows: pre-test speed $1 \mathrm{~mm} / \mathrm{s}$, probe test speed $2 \mathrm{~mm} / \mathrm{s}$, post-test speed $10.0 \mathrm{~mm} / \mathrm{s}$, compression force $100 \mathrm{~g}$, and deformation distance $40 \mathrm{~mm}$. A single fruit was placed on a steel test platform, with the stem/ calyx axis parallel to the platform, and a force deformation curve was obtained for each test. The mechanical properties of custard apple fruit were extracted from curve in terms of hardness and fracturability.

\section{Results and Discussion}

\section{Physical properties of custard apple fruit}

The samples were separated in three lots based on size of fruit i. e. big, medium and small. These were analyzed for physical properties.

\section{Length of custard apple}

It is the maximum dimension of a custard apple. It can be observed from Table 1 that the length of fruit varied from 59.31 and $92.12 \mathrm{~mm}$ minimum and maximum, with average value $72.96 \pm 6.21 \mathrm{~mm}$ respectively.

\section{Width of custard apple}

Width of custard apple represents the approximate cross-section of the custard apple. It can be observed from Table 1 that the width of fruits varied from 51.20 and $84.28 \mathrm{~mm}$ minimum and maximum, with average value $64.29 \pm 5.94 \mathrm{~mm}$ respectively.

\section{Thickness of custard apple}

Thickness of custard apple represents the approximate cross-section of the custard apple. It can be observed from Table 1 that the thickness of fruits varied from 58.13 and90.14 $\mathrm{mm}$ minimum and maximum, with an average value $69.84 \pm 5.98 \mathrm{~mm}$ respectively.

\section{Geometric mean diameter of custard apple}

It represents length, width and thickness of custard apple. It can be observed from Table 1 that the size of fruits varied from 58.22 and $88.78 \mathrm{~mm}$ minimum and maximum with an average value of $68.87 \pm 5.32 \mathrm{~mm}$ respectively. These results are in accordance with Beerh et al., (1983), Dhumal (1994), Kad (2016), Hashmi and Pawar (2012) for the length, width, thickness and size of custard apple fruits.

\section{Arithmetic mean diameter of custard apple}

Mathematical formula was used to calculate the arithmetic mean. It can be observed from Table 1 that the arithmetic mean diameter of fruits varied from 58.23 and88.85 mm minimum and maximum, with an average value of $69.03 \pm 5.32 \mathrm{~mm}$ respectively.

\section{Sphericity of custard apple}

It signifies length, width and thickness of custard apple. It can be observed from Table 1 that the sphericity of fruits varied from 0.79 and 1.11 minimum and maximum, with an average value of $0.95 \pm 0.04$ respectively. This shows that custard apple fruit of are near to spherical. This property may be used for design of fruit grader. The similar results are also depicted by Bakane (2015) and Kachhadiya (2017).

\section{Surface area of custard apple}

It was calculated with the help of the mathematical formula. It can be observed from Table 1 that the surface area of fruits varied from 106.43 and $247.51 \mathrm{~mm}^{2}$ minimum 
and maximum, with an average value of $149.81 \pm 24.02 \mathrm{~mm}^{2}$ respectively. This parameter is important in determining spray coverage, removal of residues, respiration rate, light reflectance, and colour evaluation.

\section{Volume of custard apple}

It was calculated with the help of the mathematical formula. It can be observed from Table 1 that the volume of fruits varied from 103.28 and $366.25 \mathrm{~cm}^{3}$ minimum and maximum, with an average value of $174.05 \pm$ $43.74 \mathrm{~cm}^{3}$ respectively. Volume is an important parameter in estimation of the diffusion coefficient of shrinking systems.

\section{Weight of custard apple}

The weights of corresponding 50 fruits were recorded with the help of electronic balance with least count $0.01 \mathrm{~g}$. It can be observed from Table 2 weight of fruits (large, medium and small) varied from 63.99and $225 \mathrm{~g}$ minimum and maximum, with average value $146.49 \pm 43.26$ g respectively. A high standard deviation indicates that data points are far from the mean and there is a large variation within the sample.

\section{Seeded pulp content of custard apple}

It was determined from the ratio between weight of seeded pulp and weight of fruit. It can be observed from Table 2 that the seeded pulp for ripe fruits varied from 39.20 and $63.60 \%$ minimum and maximum, with an average value 53.29 \pm 5.79 respectively. The results are in accordance with Kachhadiya (2017).

\section{Peel Content in Custard Apple}

It was calculated from equation 7 . It can be observed from Table 2 that the seed content of fruits variedfrom 23.78 and $56.43 \%$ minimum and maximum, with an average value of $38.42 \pm 6.46 \%$ respectively.

\section{Thickness of peel}

Thickness of peel was measured after scooping the seeded pulp from fruit. It was found 3 and $8 \mathrm{~mm}$ minimum and maximum, with average value $(5.50 \pm 1.30)$ respectively (Table 2). Thickness of peel is important for deciding the clearance in processing equipment.

\section{Physical properties of custard apple seeds}

The linear dimensions, arithmetic and geometric mean diameter, sphericity, surface area and volume of custard apple seeds were investigated as presented in Table 3. The average values for length, breadth and thickness of custard apple seeds observed were $13.17 \pm 1.04,6.97 \pm 0.57$ and $5.12 \pm$ $0.44 \mathrm{~mm}$ respectively. Similarly, average values for seed size $(7.76 \pm 0.32 \mathrm{~mm})$, arithmetic mean diameter $(8.42 \pm 0.36 \mathrm{~mm})$, sphericity $(0.59 \pm 0.05)$, surface area (1.89 \pm $\left.0.16 \mathrm{~cm}^{2}\right)$ and volume $\left(0.25 \pm 0.03 \mathrm{~cm}^{3}\right)$ were calculated. Any grain, fruit and seed is described as spherical when the sphericity value is above $80 \%$ and $70 \%$ (Garnayak, 2008).

Therefore, custard apple seed cannot be described has been spherical based on the sphericty values. Seed dimensions are significant as it plays major role in determining aperture sizes for the design of processing machinery (Davies, 2010). These parameters are essential for the design of appropriate equipment for processing such as cleaning, sorting, packaging and storage processes. Similar findings are reported by Mishra et al., (2009), Davies (2014) and Pawar (2012) for physical properties of custard apple seeds. 
Table.1 Axial dimensions, size, arithmetic mean diameter, sphericity, surface area and volume of custard apple fruit

\begin{tabular}{|l|c|c|c|c|c|c|c|c|}
\hline Particulars & $\begin{array}{c}\mathbf{L} \\
(\mathbf{m m})\end{array}$ & $\begin{array}{c}\mathbf{W} \\
(\mathbf{m m})\end{array}$ & $\begin{array}{c}\mathbf{T} \\
(\mathbf{m m})\end{array}$ & $\begin{array}{c}\text { Size } \\
(\mathbf{m m})\end{array}$ & $\begin{array}{c}\text { Arithmetic Mean } \\
\text { Diameter }(\mathbf{m m})\end{array}$ & Sphericity & $\begin{array}{c}\text { Surface } \\
\text { area } \mathbf{( c m}^{\mathbf{2}} \mathbf{)}\end{array}$ & $\begin{array}{c}\text { Volume } \\
\left(\mathbf{c m}^{\mathbf{3}} \mathbf{)}\right.\end{array}$ \\
\hline Max & 92.12 & 84.28 & 90.14 & 88.78 & 88.85 & 1.11 & 247.51 & 366.25 \\
\hline Min & 59.31 & 51.20 & 58.13 & 58.22 & 58.23 & 0.79 & 106.43 & 103.28 \\
\hline Average & 72.96 & 64.29 & 69.84 & 68.87 & 69.03 & 0.95 & 149.81 & 174.05 \\
\hline SD & 6.21 & 5.94 & 5.98 & 5.32 & 5.32 & 0.04 & 24.02 & 43.74 \\
\hline Var & 38.55 & 35.28 & 35.81 & 28.33 & 28.26 & 0.00 & 577.42 & 1913.01 \\
\hline SEM & 0.88 & 0.84 & 0.85 & 0.75 & 0.75 & 0.01 & 3.40 & 6.19 \\
\hline CV (\%) & 8.51 & 9.24 & 8.57 & 7.73 & 7.70 & 4.46 & 16.04 & 25.13 \\
\hline
\end{tabular}

Table.2 Physical properties of pulp and peel of custard apple fruit

\begin{tabular}{|c|c|c|c|c|c|c|}
\hline Particulars & $\begin{array}{c}\text { Weight of } \\
\text { fruit (g) }\end{array}$ & $\begin{array}{c}\text { Weight of seeded } \\
\text { pulp (g) }\end{array}$ & $\begin{array}{c}\text { Seeded pulp } \\
\text { content (\%) }\end{array}$ & $\begin{array}{c}\text { Weight of } \\
\text { peel (g) }\end{array}$ & $\begin{array}{c}\text { Peel content } \\
(\mathbf{\%})\end{array}$ & $\begin{array}{c}\text { Thickness of } \\
\text { peel (mm) }\end{array}$ \\
\hline Max & 225 & 125.78 & 63.60 & 96.19 & 56.43 & 8.00 \\
\hline Min & 63.99 & 27.66 & 39.20 & 20.38 & 23.78 & 3.00 \\
\hline Average & 146.49 & 77.47 & 53.29 & 57.31 & 38.42 & 5.50 \\
\hline SD & 43.26 & 22.30 & 5.79 & 21.49 & 6.46 & 1.30 \\
\hline Var & 1871.78 & 497.52 & 33.49 & 461.94 & 41.70 & 1.68 \\
\hline SEM & 6.11 & 3.15 & 0.82 & 3.03 & 0.91 & 0.18 \\
\hline CV (\%) & 29.53 & 28.79 & 10.86 & 37.49 & 16.81 & 23.59 \\
\hline
\end{tabular}

Table.3 Linear dimensions, size, arithmetic mean diameter, sphericity, surface area and volume of seed for large, medium and small size custard apple fruit

\begin{tabular}{|c|c|c|c|c|c|c|c|c|}
\hline Particulars & $\begin{array}{c}\mathbf{L} \\
(\mathbf{m m})\end{array}$ & $\begin{array}{c}\mathbf{W} \\
(\mathbf{m m})\end{array}$ & $\begin{array}{c}\mathbf{T} \\
(\mathbf{m m})\end{array}$ & $\begin{array}{c}\text { Size } \\
(\mathbf{m m})\end{array}$ & $\begin{array}{c}\text { Arithmetic Mean } \\
\text { Diameter }(\mathbf{m m})\end{array}$ & $\begin{array}{c}\text { Spheric } \\
\text { ity }\end{array}$ & $\begin{array}{c}\text { Surface } \\
\left.\text { area }_{(\mathbf{c m}} \mathbf{2}\right)\end{array}$ & $\begin{array}{c}\text { Volume } \\
\left(\mathbf{c m}^{\mathbf{3}}\right)\end{array}$ \\
\hline $\mathbf{M a x}$ & 14.5 & 8 & 6 & 8.40 & 9.03 & 0.73 & 2.21 & 0.31 \\
\hline Min & 11 & 6 & 4.5 & 7.09 & 7.57 & 0.52 & 1.58 & 0.19 \\
\hline Average & 13.17 & 6.97 & 5.12 & 7.76 & 8.42 & 0.59 & 1.89 & 0.25 \\
\hline SD & 1.04 & 0.51 & 0.44 & 0.32 & 0.36 & 0.05 & 0.16 & 0.03 \\
\hline Var & 1.08 & 0.26 & 0.19 & 0.10 & 0.13 & 0.00 & 0.02 & 0.00 \\
\hline SEM & 0.15 & 0.07 & 0.06 & 0.05 & 0.05 & 0.01 & 0.02 & 0.00 \\
\hline CV (\%) & 7.89 & 7.27 & 8.58 & 4.14 & 4.25 & 7.79 & 8.26 & 12.37 \\
\hline
\end{tabular}


Table.4 Linear dimensions, size, arithmetic mean diameter, sphericity and surface area of seeded pulp for large size custard apple fruit

\begin{tabular}{|c|c|c|c|c|c|c|c|}
\hline \multirow{2}{*}{ Particulars } & \multicolumn{2}{|c|}{ Large size custard apple fruit } & Size, & Arithmetic Mean & Spheri & Surface area \\
& Diameter $(\mathbf{m m})$ & city & $\begin{array}{c}\text { arm } \\
\left(\mathbf{c m}^{\mathbf{2}}\right)\end{array}$ \\
\hline Max & 25.00 & 15.00 & 10.00 & 15.11 & 16.00 & 0.72 & 7.17 \\
\hline Min & 16.00 & 9.00 & 7.00 & 10.43 & 11.33 & 0.48 & 3.41 \\
\hline Average & 22.11 & 11.00 & 8.51 & 12.69 & 13.87 & 0.58 & 5.09 \\
\hline SD & 2.21 & 1.56 & 0.89 & 0.94 & 1.03 & 0.05 & 0.76 \\
\hline Var & 4.89 & 2.43 & 0.80 & 0.89 & 1.07 & 0.00 & 0.59 \\
\hline SEM & 0.31 & 0.22 & 0.13 & 0.13 & 0.15 & 0.01 & 0.11 \\
\hline CV (\%) & 10.01 & 14.18 & 10.50 & 7.42 & 7.46 & 8.60 & 14.86 \\
\hline
\end{tabular}

Table.5 Linear dimensions, size, arithmetic mean diameter, sphericity and surface area of seeded pulp for medium size custard apple fruit

\begin{tabular}{|c|c|c|c|c|c|c|c|}
\hline Particulars & \multicolumn{2}{|c|}{ Medium size custard apple } & Size, mm & $\begin{array}{c}\text { Arithmetic Mean } \\
\text { Diameter }(\mathbf{m m})\end{array}$ & $\begin{array}{c}\text { Sphericity } \\
\mathbf{\%}\end{array}$ & $\begin{array}{c}\text { Surface } \\
\text { area }\left(\mathbf{c m}^{\mathbf{2}}\right)\end{array}$ \\
\cline { 2 - 7 } & $\mathrm{L}(\mathrm{mm})$ & $\mathrm{W}(\mathrm{mm})$ & $\mathrm{T}(\mathrm{mm})$ & & & & \\
\hline Max & 25.00 & 13.00 & 9.00 & 13.39 & 15.00 & 0.77 & 5.63 \\
\hline Min & 12.00 & 8.00 & 5.00 & 8.65 & 9.00 & 0.52 & 2.35 \\
\hline Average & 16.66 & 9.99 & 6.81 & 10.39 & 11.15 & 0.63 & 3.41 \\
\hline SD & 2.19 & 1.05 & 0.72 & 0.80 & 0.96 & 0.06 & 0.55 \\
\hline Var & 4.79 & 1.10 & 0.52 & 0.64 & 0.91 & 0.00 & 0.30 \\
\hline SEM & 0.31 & 0.15 & 0.10 & 0.11 & 0.14 & 0.01 & 0.08 \\
\hline CV (\%) & 13.14 & 10.48 & 10.58 & 7.69 & 8.56 & 8.99 & 15.99 \\
\hline
\end{tabular}

Table.6 Linear dimensions, size, arithmetic mean diameter, sphericity and surface area of seeded pulp for small size custard apple fruit

\begin{tabular}{|c|c|c|c|c|c|c|c|}
\hline \multirow[t]{2}{*}{ Particulars } & \multicolumn{3}{|c|}{$\begin{array}{c}\text { Small size custard apple } \\
\text { fruit }\end{array}$} & \multirow[t]{2}{*}{$\begin{array}{l}\text { Size, } \\
\text { mm }\end{array}$} & \multirow[t]{2}{*}{$\begin{array}{l}\text { Arithmetic Mean } \\
\text { Diameter (mm) }\end{array}$} & \multirow[t]{2}{*}{ Sphericity } & \multirow[t]{2}{*}{$\begin{array}{c}\text { Surface } \\
\text { area }\left(\mathrm{cm}^{2}\right)\end{array}$} \\
\hline & $\mathrm{L}(\mathrm{mm})$ & $\mathrm{W}(\mathrm{mm})$ & $\mathrm{T}(\mathrm{mm})$ & & & & \\
\hline Max & 17.00 & 8.00 & 7.00 & 9.84 & 10.67 & 0.63 & 3.04 \\
\hline Min & 13.00 & 6.00 & 5.00 & 7.49 & 8.33 & 0.49 & 1.76 \\
\hline Average & 14.77 & 7.29 & 5.62 & 8.44 & 9.23 & 0.57 & 2.24 \\
\hline SD & 1.02 & 0.61 & 0.70 & 0.49 & 0.49 & 0.03 & 0.26 \\
\hline Var & 1.03 & 0.37 & 0.49 & 0.24 & 0.24 & 0.00 & 0.07 \\
\hline SEM & 0.14 & 0.09 & 0.10 & 0.07 & 0.07 & 0.00 & 0.04 \\
\hline $\mathrm{CV}(\%)$ & 6.88 & 8.32 & 12.40 & 5.78 & 5.35 & 5.86 & 11.73 \\
\hline
\end{tabular}


Table.7 Mechanical properties of large, medium and small size custard apple fruit

\begin{tabular}{|c|c|c|c|c|c|c|}
\hline \multirow{2}{*}{ Particulars } & \multicolumn{2}{|c|}{ Large size fruit } & \multicolumn{2}{c|}{ Medium size fruit } & \multicolumn{2}{c|}{ Small size fruit } \\
\cline { 2 - 7 } & Hardness, & Fracturability, & Hardness, & Fracturability, & Hardness, & Fracturability, \\
& N & N & N & N & N & N \\
\hline Max & 680.26 & 40.00 & 146.97 & 40 & 124.07 & 40.00 \\
\hline Min & 440.48 & 10.71 & 21.791 & 6.178 & 17.49 & 20.39 \\
\hline Average & 586.73 & 25.71 & 80.23 & 23.86 & 70.55 & 36.08 \\
\hline S.D. & 116.26 & 16.51 & 47.95 & 15.17 & 50.98 & 8.77 \\
\hline Var & 13515.41 & 272.61 & 2299.31 & 230.38 & 2599.39 & 76.93 \\
\hline SEM & 58.13 & 8.26 & 19.57 & 6.20 & 22.80 & 3.92 \\
\hline CV $(\%)$ & 19.81 & 64.23 & 59.76 & 63.59 & 72.27 & 24.31 \\
\hline
\end{tabular}

The custard apple seeded pulp linear dimensions namely length, width and thickness measured for large size fruit $(88.78$ $\mathrm{mm}$ ) were $22.11 \pm 2.21 \mathrm{~mm}, 11 \pm 1.56 \mathrm{~mm}$ and $8.51 \pm 0.89 \mathrm{~mm}$ respectively. The size, arithmetic mean diameter, sphericity and surface area with their mean and standard deviation were found to be $12.69 \pm 0.94 \mathrm{~mm}$, $13.87 \pm 1.03 \mathrm{~mm}, 0.58 \pm 0.05$ and $5.09 \pm 0.76$ $\mathrm{cm}^{2}$ respectively (Table 4). Based on the measured dimensions of seeded pulp it will help in suggesting different aperture sizes for their processing operations. The results on physical properties of seeded pulp is in line with the results obtained by Davis (2014)

From Table 5 it can be seen that the linear dimensions of custard apple seeded pulp such as length, width and thickness measured for medium size fruit $(68.87 \mathrm{~mm})$ were $16.66 \pm 2.19 \mathrm{~mm}, 9.99 \pm 1.05 \mathrm{~mm}$ and $6.81 \pm 0.72$ $\mathrm{mm}$ respectively. The size, arithmetic mean diameter, sphericity and surface area with their mean and standard deviation were found to be $10.39 \pm 0.80 \mathrm{~mm}, 11.15 \pm 0.96 \mathrm{~mm}$, $0.63 \pm 0.06$ and $3.41 \pm 0.55 \mathrm{~cm}^{2}$ respectively. Based on the measured dimensions of seeded pulp it will help in suggesting different aperture sizes for their processing operations.

It can be seen from Table 6 that the linear dimensions such as length, width and thickness ()of custard apple seeded pulp measured for small size fruit (58.22 $\mathrm{mm}$ )were $14.77 \pm 1.02 \mathrm{~mm}, 7.29 \pm 0.61 \mathrm{~mm}$ and $5.62 \pm$ $0.70 \mathrm{~mm}$ respectively. The size, arithmetic mean diameter, sphericity and surface area with their mean and standard deviation were found to be $8.44 \pm 0.49 \mathrm{~mm}, 9.23 \pm 0.49 \mathrm{~mm}$, $0.57 \pm 0.03$ and $2.24 \pm 0.26 \mathrm{~cm}^{2}$ respectively. Any grain, fruit and seed is described as spherical when the sphericity value is above $80 \%$ and $70 \%$ (Garnayak, 2008). Therefore, custard apple seed cannot be described has been spherical based on the sphericty values. Based on the measured dimensions of seeded pulp it would help in suggesting different aperture sizes for their processing operations.

\section{Mechanical properties of custard apple fruit}

The average values recorded for hardness and fracturability of large, medium and small custard apple fruit were586.73 \pm 116.26 and $25.71 \pm 16.51 \mathrm{~N}, 80.23 \pm 47.95$ and $23.86 \pm$ $15.17 \mathrm{~N}, 70.55 \pm 50.98$ and $36.08 \pm$ 8.77respectively (Table 7). Medium and small fruit showed flesh firmness levels of $80.23 \mathrm{~N}$ and $70.55 \mathrm{~N}$; in large fruit these firmness levels were significantly higher. Over all, as the fruit size increased hardness and fracturability force increased in decreasing rate. As the small fruit contain less moisture than large size fruit, the moisture content of fruit affect the fracturability and is directly 
proportional to moisture content. The findings related to fruit size and force are in accordance with Reddy and Srinivas (2017) and also findings are corroborated with Sigita et al., (2013) for apple pulp, Ahmad et al., (2005) for fruit bar made from papaya and tomato and Costell et al., (1995) for sweet orange.

In conclusion the average weight, geometric mean diameter, arithmetic mean diameter, sphericity, surface areaandvolume146.49g, $68.87 \mathrm{~mm}, 69.03 \mathrm{~mm}, 0.95,149.81 \mathrm{~cm}^{2}$ and $174.05 \mathrm{~cm}^{3}$ for custard apple fruits were respectively. The seeded pulp content, peel content and thickness of peel for custard apple fruits were $53.29 \%, 38.42 \%$ and $5.50 \mathrm{~mm}$ respectively. The mechanical force required to compress the fruit reduced with respect to fruit size for this variety. Variation in seeded pulp for different size of fruits is important for deciding the apertures size of sieve of processing machineries. These data are important in determining the optimum stage of maturity for fruit processing.

\section{References}

Ahmad, S., A. K. Vashney and Srivasta, P.K. 2005. Quality attributes of fruit bar made from papaya and tomato by incorporating hydrocolloids. International Journal of Food Properties. 8(1): 89-99.

Bakane, P. H., P. A. Borkar., M. Gajabe and Khakare, M. 2015. Physical properties of custard apple fruit (Annona squamosa L.). International Journal of Agricultural Science and Research. Vol. 5, Issue 4, 343-352.

Beerh, O. P., N. Giridhar and Raghuramaiah, B. 1983. Custard apple (Annona squamosa) Part-I PhysicoMorphological characters and chemical composition. CFTRI Experiment Station, Hyderabad.
Costell, E., C. Trujillo, M.H. Damasio and Duran, L.1995. Texture of sweet orange gels by free-choice profiling. Journal of Sensory Studies. 10 (2): 163-179.

Dashora, L.K., N.L. Senand Maurya, I.B. 2004. Production technology of underutilized fruit crops. Yash Publishing House, Bikaner, Pp.92.

Davies, R. M. 2010. Some physical properties of arigo seeds. Int. Agrophysics. 24:8992.

Davies, R. M. A. and Mohammed, U. S. 2014.Physical and Mechanical Properties of Soursop (Annona muricata). Journal of Advanced \& Applied Sciences. Vol. 2 (1): 7-16.

Dhumal, N.S. 1994. Studies on processing of custard apple (Annona squamosa L.). M.Sc (Agri.) thesis, Mahatma Phule Krishi Vidyapeeth, Rahuri (MS).

Garnayak, D. K., R. C. Pradhan, S. N. Naik and Bhatnagar, N. 2008. Moisturedependent physical properties of jatropha seed (Jatropha curcas L.). Industrial Crops and Products.27: 123129.

Hashmi, S. I. and Pawar, V.N. 2012. Studies on physical and chemical characteristics of custard apple fruit pulp from different locations. Journal of Dairying, Foods and Home Sciences. 31(2): 117-120.

Hosakote, M., N. YashodaTyakal and Rudrapatnam, N. 2005. Mango ripening chemical and structural characterization of pectic and hemicellulosic polysaccharides. Carbohydrate Research. 340(1): 1335-1342.

Jha, S. K., S. Sethi, M. Srivastav, A.K. Dubey, R.R. Sharma, D.V.K. Samueland Singh, A. K. 2010. Firmness characteristics of mango hybrids under ambient storage. Journal of Food Engineering. 97, 208-212.

Kachhadiya, S., and Jethva, K. R. 2017. Physico-Chemical Properties of Custard 
Apple. International Journal of Biochemistry Research \& Review. 20(1): 1-13,

Kad, V. P., M. S. Jadhav and Nimbalkar, C. A. (2016) Studies on physical, morphological and rheological properties of custard apple (Annona squamosa $\mathrm{L}$ ). International Journal of Applied and Pure Science and Agriculture. 2(04), 140-147.

McCabe, W. L., J. C. Smith and Harriott, P. 1986. Unit operations of chemical engineering. New York: McGraw-Hill.

Mishra, A. K. and Kulkarni, S. D. 2009. Physical properties of cumin seeds as a function of moisture content. Agricultural Engineering Today. 33(1): 33-40.

Okoro, C. K. and Osunde, Z. D. 2013. International Journal of Engineering Research and Technology. 3(2):123129.

Pawar, D.A. 2012. Design and development of custard apple pulp-flakes extracting machine. M. Tech. (Agril. Engg.) thesis, Mahatma Phule Krishi Vidyapeeth, Rahuri (MS).

Peleg, M. 1996. Texture profile analysis parameters obtained by an instron universal testing machine. Journal of Food Science.41:721.

Reddy, B. S., and Srinivas, P. 2017 Effect of fruit size and maturity on selected mechanical properties of tomato. Int. J. Pure App. Biosci. 5 (4): 1730-1737.

Salisbury F. B. and RossC. W. 1994. Fisiología vegetal. Grupo Editorial Iberoamérica S. A., México. Pp. 759.
Sharma, S. K., R. K. Dubey and Teckchandani, C. K. 1985. Engineering properties of black gram, soybean and green gram. Proc. Indian Soc. Agric. Eng. 3:181-185.

Sigita, Boca, RutaGaloburda, IntaKrasnova, DalijaSelina, AivarsAboltins and ImantsSkrupskis. 2013. Evaluation of rheological properties of apple mass based desserts. World Academy of Science. Engineering and Technology.7:7-22.

Singh, K. K. and Sreenivasula, B. R. 2006. Post-harvest physico-mechanical properties of orange peel and fruit. Journal of Food Engineering. 73, Pp. 112-120.

Sreenarayanan, V. V., V. Subramanian and Visvanathan, R. 1985. Physical and thermal properties of soyabean. Proc. Indian Soc. Agric. Engg. 3: 161-169.

Taiz, L., and Zeiger, E. 2010. Plant physiology. Sinauer Associates, Sunderland, Massachusetts.Pp. 700.

Telis-Romero, J., C.I. Beristain, A. L. Abas and Telis, V.R. N. 2007. Effect of apparent viscosity on the pressure drop during fluidized bed drying of soursop pulp. Chemical Engineering and Processing. 46: 684-694.

Wu, B.H., B. Quilot, M. Génard, J. Kervella and Li S. 2005. Changes in sugar and organic acid concentrations during fruit maturation in peaches (Prunus davidiana) and hybrids as analyzed by principal component analysis. Scientia Horticulturae. 103(4): 429-439.

\section{How to cite this article:}

Sonali C. Khanbarad and Bakane, P. H. 2020. Physical and Mechanical Properties of Custard Apple Fruit (Annona squamosa L.). Int.J.Curr.Microbiol.App.Sci. 9(09): 2338-2347. doi: https://doi.org/10.20546/ijcmas.2020.909.292 